\title{
Secondary raw materials of agricultural processing companies as a source of anthocyanin colorants
}

\author{
Marina Shkolnikova, Olga Chugunova, and Svetlana Ivanova \\ Ural State University of Economics, 620144, Yekaterinburg, Russian Federation
}

\begin{abstract}
Many recent researches in vitro and in vivo proved the large therapeutic potency of non-toxic anthocyans in anti-inflammatory, antiinfective, anti-oxidative actions. Anthocyanin is a natural phenolic colorant approved in many countries. A reason why the world market of natural food colorants is reduced is because fruit and berry raw materials are expensive. Yet the fruit and berry raw materials are extracted with significant losses and by-products. This constitutes around $23-45 \%$ of the whole amount of berries processes in the Russian Federation. Thus, a priority direction of the food industry is a development of technologies allowing to use precious berry pomace with high bioactive compounds, i.e. anthocyans, organic acids, pectin. The aim of the research is to extract food colorant from the pomace of Vaccínium myrtíllus and Vaccínium vítisidaéa to identify individual anthocyanin pigments. The food safety and composition of the pomace of Vaccinium myrtillus and Vaccinium vitisidaea as raw material for food colorant extraction were found. Individual anthocyanin pigments of anthocyanin extracts were identified through the method of high-performance liquid chromatography. Cyanidin-3galactoside was found in the extracts of berries $(85,6 \%)$ and pomaces $(81,2 \%)$ of Vaccinium vitis-idaea. Fifteen compounds were identified in the extracts of Vaccinium myrtillus. The major ones were delphinidin-3glucoside $(13,4 \%)$, delphinidin-3-galactoside (12,4\%), and cyanidin-3glucoside for the fresh berries. As for the pigments of its pomaces, they were delphinidin-3-glucoside (15,3\%), delphinidin-3-galactoside (14,7\%), and delphinidin-3-arabinoside (10,5\%). Hence, there are more anthocyanin pigments in the extracts of pomaces, than in those of the fresh berries with identical compounds - 24,7\% more for Vaccinium myrtillus and $11,1 \%$ more for Vaccinium myrtillus. The possibility to extract anthocyanin pigments from by-products of the local fruit and berry raw materials - i.e. of Vaccinium myrtillus and Vaccinium vitis-idae ones - and identify them is discussed.
\end{abstract}

\section{Introduction}

The color is a basic characteristic of food stuff that indirectly makes consumers choose a product and estimate its quality. «Clean label» and «Free from All» global trends are becoming popular with Russians. This stimulates demands for products made of natural raw 
materials and colorants. Nearly $70 \%$ of interviewed from Western Europe study the food label before buying a product. Three quarters of them consider the "No artificial ingredients" indication crucial, according to the Mintel market research firm [1-3].

Such researches prove the opinion, that the last decade saw a fast-growing segment of consumers, taking care of their health, appear. This is what market experts and specialists on healthy nutrition figure. They are usually educated and well-informed people searching for sources of commercial and scientific information to health promotion. Advertisements are distrusted [4].

Coloring food technologies must meet many requirements. The colorant must be safe, temperature resistant, durably high-color and have no off-flavors. Chemical compound and properties of a natural colorant are inferior to those of the synthetic ones. They are less resistant to storing and production load. Though, natural plant colorants are sometimes obligatory as in case with fermented milk products. Lactic acid bacteria decompose synthetic azo dyes in several hours - the anaerobic degradation of azo dyes is a key concept for technologies reducing pollution of ecosystems. Thus, acid-tolerant natural pigments should be used to dye some products [5-8].

Besides, synthetic colorants prevailing on the Russian market are often non-conform to the main requirements. Colorants used in food are proved to cause physiological failures, allergies, and severe chronic diseases $[9,10]$.

Natural colorants, including anthocyanin, not only dye food products but also have health promoting properties proved in vitro and in vivo. Natural colorants proved non-toxic have anti-inflammatory, anticarcinogenic, and antibacterial potency; ease oxidative stress; prevent heart diseases, obesity, and visual impairment; controls diabetes (WHO, 1982) [11$15]$.

Natural anthocyans as color additive for food and drinks are approved in many countries. Nowadays the market sees the growing demands for natural food colorants, mainly the red ones [16]. Yet the world market of natural food colorants is reduced as the technologies are complex and fruit and berry raw materials are expensive. The local fruit and berry raw materials are still extracted with significant losses and by-products (23-45 \%). For example, in Altai Krai only the losses constitute around 860-870 tones, which results from a low depth of processing and lack of innovative decisions on berry marcs processing.

Purpose of the study. Thus, the economic situation and the fact of ecology deterioration make the problem of depth of processing of fruit and berry secondary raw material crucial. So, the search of new raw materials for anthocyanin colorants is relevant. The aim of the research is to extract food colorant from the pomace of Vaccínium myrtíllus and Vaccínium vítis-idaéa to identify individual anthocyanin pigments.

\section{Materials and methods}

The subjects of the research are the samples of pomaces and ethanolic extracts of anthocyans. The samples of pomaces of Vaccínium myrtíllus and Vaccínium vítis-idaéa (fig. 1) are the wastes of technological cycle of dry extracts production from a going concert. The LLC "KIT" Altai Krai specializes in processing of local fruit and berry raw material. The feedstock is standardized in accordance with GOST 34219-2017, GOST 20450-75 и TRCU 021/2011 requirements, according to the specification. The extracts of anthocyans were extracted from a mixture of ethyl alcohol $(60 \%)$ and hydrochloric acid (1\%) incubating in water bath for 1.5 hour. The solution was further cooled to room temperature and filtrated from foreign matters. The method was chosen because the extraction of anthocyans by ethyl alcohol gives a more concentrated colorant [17]. The 
extracts of Vaccínium myrtíllus and Vaccínium vítis-idaéa were the control samples obtained likewise.

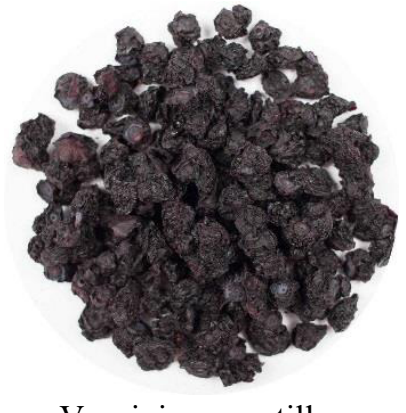

Vaccinium myrtillus

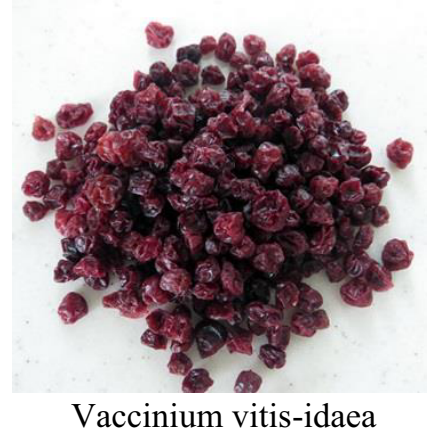

Vaccinium vitis-idaea

Fig. 1. Dried samples of the pomaces

Physical and chemical features of the pomaces were analyzed through standard methods. The mass concentration of the juice was found through the thermogravimetric analysis as per GOST 28561. The method presupposes that a friable or allocated on the absorbing surface sample would be dried on high temperature and controlled pressure. The mass concentration of the titratable organic acids (expressed as malic acid) was measured by potentiometric titration as per GOST 25555.0-82. The solution was subject to potentiometric titration to $\mathrm{pH} 8,1$. The solution is titrated and constantly interfused with sodium hydroxide $(\mathrm{NaOH})=0,1 \mathrm{~mol} / \mathrm{dm} 3$. The interfusing is fast until $\mathrm{pH} 6,0$, then slowly until $\mathrm{pH} 7,0$. Four drops of a titrant are pored next several times until $\mathrm{pH}$ is 8,1 . The amount of the titrant and the $\mathrm{pH}$ level are noted alongside. After the $\mathrm{pH} \mathrm{8,1} \mathrm{is} \mathrm{reached,} \mathrm{no} \mathrm{less} \mathrm{than}$ 4 drops of sodium hydroxide are added. The mass concentration of sugars was defined by photocolorimetry as per GOST $8756.13-87$. The method is based on interaction of carbonyl group of sugars with potassium ferricyanide in basic conditions and optical density measurement of the solution obtained by photoelectrocolorimeter. The mass concentration of extractives was specified through gravimetric single-contact extraction analysis as per general pharmacopoeia article 1.5.3.0006.15. The mass concentration of pectin (protopectin) by the method as per GOST 29059-91. The method is to titrate a substance preliminary isolated from pectin substances before and after hydrolysis. The results of the titration are proportional to the amount of the free and etherified carboxyl groups. The multiplication of them by corresponding equivalents results in content of polyuronides in pectin substances of a product. The mass concentration of anthocyans in the samples of the extracts was precised per GOST 32709-2014. The anthocyans were identified by the method of high-performance liquid chromatography (HPLC). The ethanolic extracts were separately chromatographed in liquid chromatograph Agilent 1200 under the following conditions: the column Luna $5 \mathrm{uC18}(2) 100 \mathrm{~A}(250 \mathrm{x} 4,6 \mathrm{~mm} 5 \mu \mathrm{m})$; the temperature of the heat block $25^{\circ} \mathrm{C}$; the detection wavelength $543 \mathrm{~nm}$; the MECN eluent; the solution of the phosphoric acid in water $(0,01 \%)$; gradient eluting. The collection of data, the processing of chromatograms and absorption spectra were realized in the AgilentChemStation. The peaks were identified according to literature data and the holding time was compared for the analogical columns [18]. 


\section{Results and discussion}

The organoleptic assessment of the samples proved that the pomaces are composed of undamaged homogeneous sphere fruits 5-7 $\mathrm{mm}$ in diameter. Those of the Vaccínium myrtíllus were violet with palatability, sweetness and the strong taste of the initial raw material. The Vaccínium vítis-idaéa ones were crimson with palatability, sweet and sour strong taste. Composition of the samples of the pomaces are presented in the table 1.

Table 1. Composition of the samples of the pomaces on a dry basis $(n=3, M \pm m)$

\begin{tabular}{|c|c|c|c|c|c|c|}
\hline \multirow{2}{*}{ Pomaces } & \multicolumn{5}{|c|}{ Concentration, \% } \\
\cline { 2 - 7 } & juice & $\begin{array}{c}\text { organic } \\
\text { acids (ex- } \\
\text { pressed as } \\
\text { malic acid) }\end{array}$ & sugars & extractives & $\begin{array}{c}\text { pectin substanc- } \\
\text { es (protopectin) }\end{array}$ & anthocyans \\
\hline $\begin{array}{c}\text { Vaccinium } \\
\text { vitis-idaea }\end{array}$ & $\begin{array}{c}4,91 \pm 0, \\
11\end{array}$ & $4,52 \pm 0,10$ & $3,2 \pm 0,1$ & $60 \pm 1,0$ & $3,1 \pm 0,2$ & $\begin{array}{c}0,504 \pm 0,00 \\
1\end{array}$ \\
\hline $\begin{array}{c}\text { Vaccinium } \\
\text { myrtillus }\end{array}$ & $\begin{array}{c}3,57 \pm 0, \\
11\end{array}$ & $4,89 \pm 0,10$ & $3,7 \pm 0,1$ & $71 \pm 1,0$ & $3,6 \pm 0,2$ & $\begin{array}{c}0,612 \pm 0,00 \\
1\end{array}$ \\
\hline
\end{tabular}

The data obtained matches with those of the literature [19].

The food colorings as well as other raw materials for foodstuff must conform to the requirements on safety points, i.a. microbiological ones proved experimentally (table 2).

Table 2. Microbiological safety points for the samples of the pomaces $(n=3, M \pm m$ )

\begin{tabular}{|l|c|c|c|c|}
\hline $\begin{array}{c}\text { Type of raw materi- } \\
\text { al }\end{array}$ & $\begin{array}{c}\text { Mesophilic anaero- } \\
\text { bic and optionally } \\
\text { anaerobic microor- } \\
\text { ganisms max ufc/1g }\end{array}$ & $\begin{array}{c}\text { Yeast max } \\
\text { ufc/g }\end{array}$ & $\begin{array}{c}\text { Mold } \\
\mathbf{m a x} \\
\text { ufc/g }\end{array}$ & $\begin{array}{c}\text { Coliform } \\
\text { bacteria pro- } \\
\text { hibited in the } \\
\text { product in } \mathbf{g}\end{array}$ \\
\hline $\begin{array}{l}\text { Norms of TRCU 021, } \\
\text { mg/kg, max }\end{array}$ & $5,0 \cdot 10^{4}$ & 200 & 500 & 0,1 \\
\hline Vaccinium myrtillus & $<20$ & $<15$ & \multicolumn{2}{|c|}{ Not found } \\
\hline Vaccinium vitis-idaea & $<10$ & $<20$ & \multicolumn{2}{|c|}{ Not found } \\
\hline
\end{tabular}

The data of the table 2 show that the samples of the pomaces are safe. This also proves that sanitary and hygienic requirements of storage and processing of the raw material are met.

The concentration of anthocyanin colorants in the extracts may be estimated by the absorbency intensity of the dyed samples as well. Thus, this stage of the research presupposed the comparison of the anthocyanin colorants content in the extracts made of pomaces and fresh berries. Having analyzed the absorbency of the extracts of extracts and fresh berries of Vaccínium myrtíllus and Vaccínium vítis-idaéa, the growth of the absorbency was confirmed (table 3). This attests that the concentration of the dyed substances in the extracts of the pomaces is bigger.

Table 3. Absorbency of the extracts of Vaccínium myrtíllus and Vaccínium vítis-idaéa at the wavelength $543 \mathrm{~nm}$

\begin{tabular}{|l|c|c|}
\hline \multirow{2}{*}{ Type of raw material } & \multicolumn{2}{|c|}{ Absorbency, $\mathbf{n m}$} \\
\cline { 2 - 3 } & Fresh berries & Pomaces \\
\hline Vaccinium vitis-idaea & 0,632 & 0,793 \\
\hline
\end{tabular}




\begin{tabular}{|l|c|c|}
\hline Vaccinium myrtillus & 0,234 & 0,258 \\
\hline
\end{tabular}

Many chemical compounds are known to have electronic signals allowing to examine their structure. The dyed compounds, i.e. those of anthocyans, have intense signals comprised between 400 and $600 \mathrm{~nm}$. Their absorbency peaks relate directly to the structure and polymerization degree of an anthocyanin. The fig. 2 presents the absorbency of anthocyanin ethanolic extracts made of pomaces of Vaccinium vítis-idaéa (1) and Vaccínium myrtillus (2) and the fresh berries (3), (4) resp.

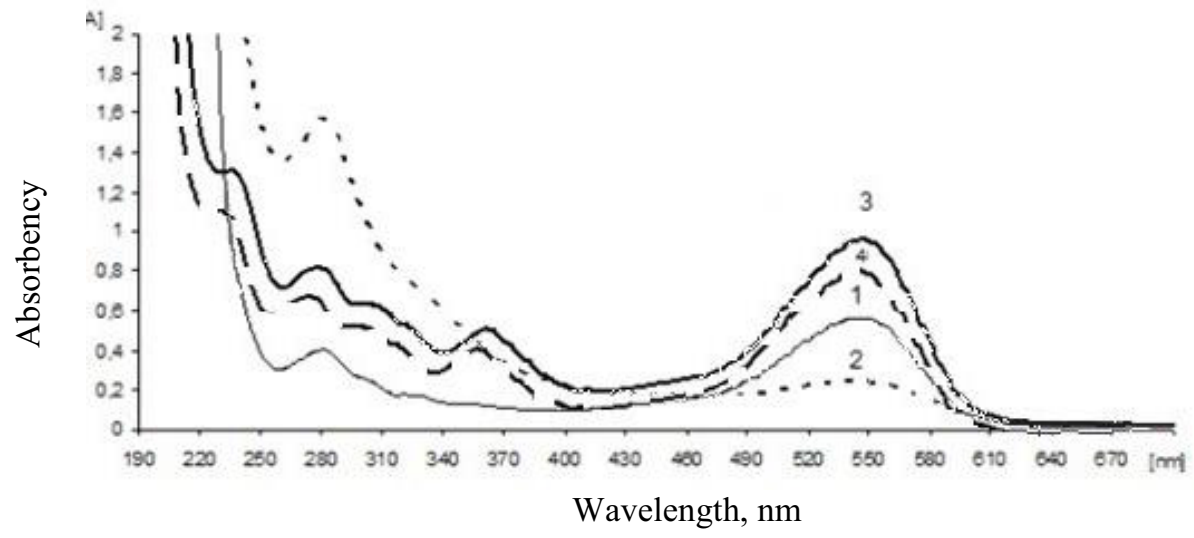

1 - pomaces Vaccinium vitis-idaea; 2 - fresh berries Vaccinium vitis-idaea; 3 - pomaces Vaccinium myrtillus, 4 - fresh berries Vaccinium myrtillus

Fig. 2. Absorbency spectra of anthocyanin ethanolic extracts of Vaccínium vítis-idaéa and Vaccínium myrtíllus

The fig. 2 demonstrates that the extract of the pomaces of Vaccínium vítis-idaéa has two absorbency peaks in UV $282 \pm 2 \mathrm{~nm}$ and VIS $541 \pm 2 \mathrm{~nm}$. The peak of the extract of the pomaces of Vaccinium myrtillus is in VIS $543 \pm 2 \mathrm{~nm}$, UV $281 \pm 2 \mathrm{~nm}$, and shoulder in 370 $\mathrm{nm}$. The peak of the extract of the fresh berries of Vaccínium vítis-idaéa is in UV $279 \pm 2$ $\mathrm{nm}$ and VIS $537 \pm 2 \mathrm{~nm}$. The peaks of the extract of the fresh berries of Vaccinium myrtillus are in UV $281 \pm 2 \mathrm{~nm}$ and VIS $543 \pm 2 \mathrm{~nm}$, and shoulder in $370 \mathrm{~nm}$. The absorbency spectra of the ethylic extracts may have 3 peaks of adsorption in the UV area comprised between 260 and $380 \mathrm{~nm}$, according to literature data. This may be used to estimate amount of acyl fragments in the structure. The degree of decarboxylation may displace the peaks, as shown in the fig. 2 for the samples 3 and 4.

The data obtained experimentally enabled to figure the amount of anthocyans on a basis of cyanidin-3,5-diglucoside in dry raw material (table 4).

Table 4. The amount of anthocyans on a dry basis of cyanidin-3,5-diglucoside

\begin{tabular}{|l|c|c|}
\hline \multirow{2}{*}{ Type of raw material } & \multicolumn{2}{|c|}{ Total amount of anthocyans, \% } \\
\cline { 2 - 3 } & Fresh berries & pomaces \\
\hline Vaccinium vitis-idaea & 1,21 & 1,51 \\
\hline Vaccinium myrtillus & 0,45 & 0,50 \\
\hline
\end{tabular}

According to the table 4, the biggest amount of anthocyans on a basis of cyanidin-3,5diglucoside is in the Vaccinium myrtillus. More anthocyans were found in the pomaces, as anthocyans and pectin are mostly localized in the skin and not in the pulp. The literature data says that the amount of anthocyans in the skin is $6,8-10,8$ times over than in the pulp [20]. 
The compound of the anthocyans was further identified by the method of chromatography. The results are presented in the tables 5 and 6 .

Table 5. Results of the HPLC of the extracts of berries and pomaces of Vaccinium vitis-idaea

\begin{tabular}{|c|l|c|c|c|c|}
\hline \multirow{2}{*}{ № } & \multirow{2}{*}{ Compounds } & \multicolumn{2}{|c|}{ Retention time, min } & \multicolumn{2}{c|}{ Content of samples, \% } \\
\cline { 3 - 6 } & & Berries & Pomaces & Berries & Pomaces \\
\hline 1 & Cyanidin-3-galactoside & 8,708 & 27,320 & 85,6 & 81,2 \\
\hline 2 & Non identified & 9,748 & 31,089 & 4,9 & 3,2 \\
\hline 3 & Petunidin-3-galactoside & 10,863 & 33,889 & 9,4 & 15,5 \\
\hline
\end{tabular}

The table 5 demonstrate that the extracts have two peaks. The first one is presumably the peak 1 of cyanidin-3-galactoside and the second one is the peak 3 of petunidin-3galactoside. These are the most concentrated anthocyans which is also described in the literature $[18,20-22]$. The quality compound of anthocyans usually differs between botanic species and it is stable except for different geographical ranges and climate conditions. Hence, anthocyanin complex of the berries of Vaccinium vitis-idaea compounds glycosylated cyanidin and petunidin with residues of galactose in position $\mathrm{C}-3$ of heterocycle ring C- .

Table 6. Results of the HPLC of the extracts of berries and pomaces of Vaccinium myrtillus

\begin{tabular}{|l|l|c|c|c|c|}
\hline \multirow{2}{*}{ № } & \multirow{2}{*}{ Compounds } & \multicolumn{2}{|c|}{ Retention time, min } & \multicolumn{2}{c|}{$\begin{array}{c}\text { Content of the compo- } \\
\text { nent, \% }\end{array}$} \\
\cline { 3 - 6 } & & berries & pomaces & berries & pomaces \\
\hline 1 & Delphinidin-3-galactoside & 21,462 & 21,498 & 12,4 & 14,7 \\
\hline 2 & Delphinidin-3-glucoside & 24,689 & 24,780 & 13,4 & 15,3 \\
\hline 3 & Cyanidin-3-galactoside & 26,800 & 26,913 & 10,4 & 7,4 \\
\hline 4 & Delphinidin-3-arabinoside & 27,856 & 27,980 & 10,5 & 10,5 \\
\hline 5 & Cyanidin-3-glucoside & 30,788 & 30,912 & 11,6 & 8,5 \\
\hline 6 & Petunidin-3-galactoside & 33,090 & 33,209 & 3,4 & 5,2 \\
\hline 7 & Cyanidin -3- arabinoside & 36,752 & 33,618 & 9,4 & 4,9 \\
\hline 8 & Petunidin-3-glucoside & 38,870 & 36,866 & 2,1 & 9,6 \\
\hline 9 & Delphinidin & 39,933 & 39,004 & 2,9 & 0,7 \\
\hline 10 & Peondin-3- galactoside & 41,499 & 39,321 & 4,9 & 0,9 \\
\hline 11 & Petunidin -3- arabinoside & 41,882 & 40,009 & 3,5 & 2,4 \\
\hline 12 & Peondin -3- glucoside & 42,573 & 41,544 & 0,6 & 3,6 \\
\hline 13 & Malvidin -3-galactoside & 42,928 & 41,918 & 9,9 & 3,6 \\
\hline 14 & Peondin -3- arabinoside & 43,904 & 42,611 & 3,2 & 0,4 \\
\hline 15 & Malvidin-3- glucoside & 45,557 & 42,958 & 0,6 & 9,6 \\
\hline 16 & Non identified & 48,549 & 43,933 & 0,2 & 1,9 \\
\hline 17 & Non identified & 49,453 & 45,586 & 0,9 & 0,3 \\
\hline
\end{tabular}

Seventeen anthocyans of the extracts of the fresh bilberries were found with 15 identified. The most concentrated ones are cyanidin-3-galactoside, petunidin-3-galactoside, malvidin -3- galactoside, delphinidin-3-arabinoside, petunidin -3- arabinoside.

Seventeen components of the extracts of pomaces of the bilberries with 15 identified. The most concentrated anthocyans are cyanidin-3-galactoside, peondin -3-glucoside, delphinidin-3-arabinoside, peondin-3- galactoside, delphinidin-3-glucoside.

As shown in the table 6, the prevailing components in the extract of the fresh berries are delphinidin-3- glucoside (13,4\%), delphinidin-3- galactoside $(12,4 \%)$, and cyanidin-3glucoside $(11,6 \%)$. As for those of the extracts of the pomaces, they are delphinidin-3glucoside (15,3\%), delphinidin-3- galactoside (14,7\%), and delphinidin-3-arabinosid (10,5 $\%)$. 


\section{Conclusions}

The reaches revealed that there are more anthocyanin pigments in the extracts of pomaces, than in those of the fresh berries with identical compounds $-24,7 \%$ more for Vaccinium myrtillus and $11,1 \%$ more for Vaccinium myrtillus. The analysis proved that compounds of the extracts of fresh berries and pomaces differ in quality and in quantity. The most concentrated anthocynas with diverse compound are in the extracts of the berries and pomaces of Vaccinium myrtillus. Fifteen anthocyans were identified in them, while in those of Vaccinium vitis-idaea only 2. Besides, only 2 compounds are identified in all the samples. They are cyanidin-3-galactoside (prevailing in the extracts of berried and pomaces of Vaccinium vitis-idaea $-85,6 \%$ and $81,2 \%$ resp.) and petunidin-3-galactoside. The fact suggests that the colorants made of pomaces of Vaccinium vitis-idaea would result in a higher anti-oxidative potency of food stuff. The research [23] shows that the antioxidative potency of the cyanidin-3- glucoside is higher than of other anthocyans. It is $75 \%$ higher than of cyanidin-3-galactoside and $90 \%$ higher than of the peondin-3-glucoside.

Thus, the possibility to extract and identify anthocyanin pigments from by-products of the local fruit and berry raw materials - i.e. of Vaccinium myrtillus and Vaccinium vitisidae ones - is presented. However, the use of natural anthocyanin coloring remains individual and depends on the kind, form and compound of a product. Nevertheless, natural anthocyanin colorants are preferable as they are multifunctional and not only dye food products and render them more attractive. Stabilization of anthocyanin colorants in the food systems, their assimilability and bioavailability need further analysis.

\section{References}

1. J.L. Lusk, T.C. Schroeder, G.T. Tonsor, Eur. Review of Agricultural Economics, 41 (4), 627 (2014)

2. K. Binnur, K. Serap, American J.of Food Sci. and Nutrition Res., 2 (2), 21 (2015)

3. B. Nemzer, Z. Pietrzkowski, A. Spórna, P. Stalica, W. Thresher T. Michałowski, S. Wybraniec, Food Chemistry, 127 (1), 42 (2011) doi:10.1016/j.foodchem.2010.12.081

4. G. Grynkiewicz, Phytochemicals Between Nutrition and Medicine Acta Scientific Nutritional Health 4.1 4, 24 (2020)

5. S.K. Reshmi, K.M. Aravindhan, D.P Suganya, Asian Journal of Pharmaceutical and Clinical Research, 5 (4), 107 (2012)

6. C.S. Boon, D.J. Mc Clements, J. Weiss, E.A. Decker, Critical Reviews Food Science and Nutrition, 50 (6), 515 (2010). doi:10.1080/10408390802565889

7. G.S. Ranhotra, J.A. G elroth, J. langemeier, D.E. Rogers, Cereal Chemistry J., 72 (2), 139 (1995)

8. C.S. Tang, M.H. Norziah, J. of Chemistry, 7, 327 (2007)

9. J.C. Griffiths, Coloring Foods, Beverages, Food Technology, 59 (5), 38 (2005)

10. H.M. Neveen, J. of the Egyptian Society of Toxicology, 34, 77 (2006)

11. J. He, M. Giusti, Food Science and Technology, 1 (1), 163 (2010) doi:10.1146/annurev.food.080708.100754

12. I.V. Okunevich, N.S. Sapronov, Reviews on Clinical Pharmacology and Drug Therapy, 3 (3), 2 (2004)

13. H. Nakaishi, H. Matsumoto, S. Tominaga, M. Hirayama, Alternative Medicine Review, 5 (6), 553 (2000) 
14. G. Mazza, Ann Ist Super Sanita, 43 (4), 369 (2007)

15. B. Radovanovic, A. Radovanovic, Molecules, 15 (6), 4213 (2010)

16. E.V. Alekseenko, M.M. Azarova, Food processing industry, 9, 16 (2018)

17. V.M. Bolotov, E.V. Komarova, E.S. Filatova and V.V. Khripushin, Chemistry of plant materials, 1, 127 (2016)

18. J. Hokkanen, S. Mattila, L. Jaakola, A. Pirttila, A. Tolonen, J. Agric. Food Chem, 57, 9437 (2009)

19. O.Y. Kolman, G.V. Ivanova, T.N. Yamskikh, A.N. Ivanova, IOP Conference Series: Earth and Environmental Science, 315 (2), $022 \quad$ (2019) .doi:10.1088/1755$1315 / 315 / 2 / 022032$

20. I.A. Filatova, R.L. Filippova, A.Yu. Kolesnov and M.A. Dyachenko, Food processing industry, 1, 24 (2006)

21. F.L. Meng, X.T. Su, Y.D. Li, J. Jilin. Agric. Univ., 26, 529 (2004)

22. H. Kartimo, S. Mattila, A. Tolonen, J. Agric. Food Chem., 54, 9834 (2006)

23. M.N. Lyutikova, E.Kh. Botirov, Chemistry of plant raw material, 2, 5 (2015) 